\title{
CONTRIBUIÇÃO À HISTÓRIA DOS \\ FESTIVAIS DE TEATRO NO BRASIL
}

\section{Leidson Malan Monteiro de Castro Ferraz UNIRIO}

\section{Resumo}

Para colaborar com a investigação histórica, a proposta é reunir dados sobre os primeiros festivais de teatro no Brasil, partindo de uma certa trajetória temporal que vai dos festivais artísticos ainda em benefício aos eventos em reverência a autores, passando depois a ter o conceito moderno de reunião de atrações variadas em período e local constantes, além de atividades extras programadas. O artigo também presta homenagem àqueles que pioneiramente deram dinâmica à realização destes encontros festivos do teatro amador ou profissional de então, nos mais diversos pontos deste país, destacando aspectos de relevância social, cultural e política.

\section{Palavras-chave:}

Festivais de teatro; História; Teatro amador.

Se voltarmos nossa atenção à história dos festivais de teatro no Brasil vamos ver que a palavra se confundia, nos seus primórdios, à ideia de benefício que se podia fazer ao próximo. Realizar um festival artístico era necessariamente promover uma récita com renda voltada a uma instituição ou a um elemento da sociedade, preferencialmente dos palcos. Com caráter beneficente, ou seja, de ajuda financeira a alguém necessitado, o festival, esta "primeira e mais antiga forma de união dos que faziam teatro" (KÜHNER, 1987, p. 11), estava então atrelado à perspectiva de se fazer um bem a um conhecido e pode-se deduzir que quando ganharam o perfil que hoje nós conhecemos - reduto de apresentações que aposta na maior diversidade de atrações e atividades -, não deixaram de ser este benefício à sociedade, como um bem a todos mesmo, o compartilhamento festivo de celebração à arte.

\section{Abstract}

As to collaborate with the historical investigation, the present proposal gathers data regarding the first theatre festivals in Brazil, taking into consideration a time trajectory that varies from artistic festivals, which in benefit to the events in curtsy to authors, to concepts of modern attractions in constant different times and places, other than the extra programmed activities. This article also pays homage to those pioneers of a dynamic fulfillment of such festive gatherings in the realms of amateur and professional theatre of the period, ranging from diverse sites in the country taking into account social, cultural and political aspects.

Keywords:

Theatre festivals; History; Amateur theatre.

O chamado "espetáculo em benefício", ou simplesmente "benefício", que mais tarde ganhou a alcunha de "festival", pelo menos no nosso país, de acordo com o Dicionário do Teatro Brasileiro (GUINSBURG; FARIA; LIMA, 2006) nasceu provavelmente na França, com primeiro caso registrado em 1735, quando a equipe da Comédie Française entregou toda a renda de uma peça a uma atriz que perdera seus pertences num incêndio. No século XVIII, os benefícios ocorriam, esporadicamente, para ajudar algum artista acidentado ou em dificuldades financeiras, mas já no século XIX tornaram-se prática comum na vida teatral, prevista inclusive em contrato e considerada como uma forma de remuneração a mais dos artistas, técnicos e dramaturgos. Foi assim que o benefício ou festival se popularizou no Brasil, para socorrer aqueles que precisavam, ou então como festa para o artista beneficiado, nacional ou estrangeiro, em clara demonstração 
do seu prestígio junto ao público, à imprensa e aos seus pares.

"Seja como festa artística, seja como forma de ajuda financeira, o benefício sobreviveu ao século XIX, mas, aos poucos, desapareceu completamente dos costumes teatrais brasileiros" (GUINSBURG; FARIA; LIMA, 2006, p. 61), é o que afirma aquela publicação, informação que não procede, pois são inúmeros os registros na história da cena teatral brasileira, chegando até o início da década de 1970, dos festivais em benefício de algum artista necessitado ou mesmo como evento celebratório. Vem deste último perfil o conceito moderno dos festivais artísticos que surgiram pelo mundo na primeira metade do século $X X$.

Às vezes a gente esquece que festival é a forma adjetiva para festa: em Atenas, no século $V$, por ocasião das festas religiosas (Dionisíacas ou Leneanas), representavam-se comédias, tragédias, ditirambos. Estas cerimônias anuais marcavam um momento privilegiado de regozijo e de encontros. Deste acontecimento tradicional, o festival conservou uma certa solenidade na celebração, um caráter excepcional e pontual que a multiplicação e a banalização dos modernos festivais muitas vezes esvaziam de sentido (PAVIS, 1999, p. 166).

Entendendo que um conceito não é imutável, e pode incorporar novos sentidos, o festival passou a ser cada vez mais uma comemoração de intercâmbio cultural. O artista Marcelo Bones nos lembra do nascimento de dois emblemáticos eventos ocidentais: o Festival de Avignon, na França, e o Festival de Edimburgo, no Reino Unido, ambos em 1947 e com um impulso comum: "aglutinar artistas e contribuir para a reconstrução da Europa depois da Segunda Guerra Mundial" (BONES, 2017, p. 22). Assim, além da importância de serem mostras de espetáculos, os festivais trazem, em sua origem, "dimensões sociais e políticas".

Deduz-se ainda que um evento destes - de teatro, por exemplo -, na sua sequência de várias atrações eleitas a fazerem parte de um momento significativo, pretensamente impactante, seja um triunfo a um condensado importante da cena que chegou aos palcos, como uma fatura da produção artística teatral que vem honrar os artistas que dela fazem parte e galgar créditos com as plateias que os apreciarão. Um festival passa a ser, deste modo, um período de entusiasmo, de banquete à arte, parecendo estar o público mais receptivo a aclamar os artistas participantes, responder freneticamente àquele momento diferenciado de congraçamento coletivo a uma expressão artística direta e viva.

Valorizando, certamente, o perfil de aprendizado na interpretação e a troca com as plateias, no intuito da visibilidade que poderia advir daí, inclusive junto à imprensa, Paschoal Carlos Magno, inspirado por algo parecido que conferiu na Inglaterra, criou o Festival Shakespeare no Rio de Janeiro em 1949, o primeiro evento de teatro no Brasil a ganhar a alcunha de "festival artístico" não mais tendo a beneficência em primeiro plano. A programação, que ocorreu de maio a agosto, caracterizou-se como a prova pública dos alunos do Seminário de Arte Dramática, escola mantida pelo Teatro do Estudante do Brasil (TEB) desde 9 de agosto de 1948, em cooperação com o Serviço Nacional de Teatro (SNT). Mas nenhuma ajuda oficial foi direcionada à programação, tudo necessitando da afluência de público para cobrir as despesas, tanto que a ideia nem se concretizou como inicialmente planejada.

Três peças do bardo inglês conseguiram chegar à cena, todas no Teatro Fênix, no Rio de Janeiro: Romeu e Julieta, em cartaz a partir de 19 de maio, por três semanas consecutivas; Macbeth (ambas direção Esther Leão) e exibida a partir de 17 de junho; e, por fim, Sonho de Uma Noite de Verão (dir. Ruggero Jacobbi), em cartaz de 22 de julho a 14 de agosto de 1949. Duas outras obras, Otelo e Rei Lear, apesar de programadas, não chegaram a acontecer por conta da crise financeira que o TEB enfrentou naquele ano, assim como também não foi possível viabilizar conferências sobre a vida e obra do dramaturgo William Shakespeare, mas apenas uma exposição de trabalhos do cenógrafo e ilustrador Edouard Loeffler com cenários e figurinos de obras shakespearianas.

Os espetáculos aconteciam diariamente, com folga apenas às segundas-feiras, seguindo o que se fazia no teatro profissional, e sessões duplas aos sábados. No intuito de atingir o público infantojuvenil, Sonho de Uma Noite de Verão contou ainda com récitas diurnas, às 10 ou 14 horas, e foi a única peça em que um ator profissional convidado, Jaime Barcelos, esteve presente no elenco de estudantes. A receptividade de público e crítica foi muito boa, mas não cobriu as enormes despesas do empreendimento. Tanto que 
o Festival do Teatro Grego, que viria a seguir, foi cancelado por Paschoal Carlos Magno. Houve até provas com centenas de candidatos a intérpretes, mas o evento, que tinha como referência a experiência do Teatro da Natureza em 1916, no Campo de Santana (RJ), com apresentações num anfiteatro ao ar livre com capacidade para $10 \mathrm{mil}$ pessoas, acabou não acontecendo. Mais detalhes sobre estas iniciativas podem ser consultados em O Teatro do Estudante do Brasil de Paschoal Carlos Magno, de Fabiana Siqueira Fontana (2006), e 0 Teatro da Natureza: história e ideias, de Marta Metzler (2006).

No entanto, Paschoal Carlos Magno já se dedicava a duas novas empreitadas, concomitantemente, o Festival do Autor Novo, programado para ser lançado à meia-noite do dia 2 de agosto de 1952 (mas a ideia já vinha de dois anos antes), na inauguração do seu Teatro Duse, uma sala-laboratório com apenas cem lugares, na residência do próprio, no bairro de Santa Teresa. A programação estendeu-se até final de 1956, mesmo com a casa de espetáculos fechada por alguns períodos, a exemplo do que ocorreu de janeiro a setembro de 1953, e impulsionou a montagem de 26 textos nacionais inéditos, tudo no objetivo de despertar e revelar novas vocações dramatúrgicas no Brasil, fazendo também surgir diretores (ou confirmar talentos de pouca experiência antes), como José Maria Monteiro, B. de Paiva e o próprio Paschoal Carlos Magno, além de alguns cenógrafos e figurinistas estreantes.

O termo "festival" pode sugerir algo diferente do
que se passou no teatro de Paschoal Carlos Magno.
O evento não foi organizado, como se poderia
pensar, nos formatos tradicionais de um festival -
fato que era bem característico do Teatro Duse. Para
começar, não havia um período específico para sua
realização. Depois, sua programação era incerta e
podia ser intercalada com outros eventos do teatro
[a exemplo das temporadas de peças que já faziam
parte do repertório do próprio Teatro do Estudante do
Brasil e de grupos convidados]. Mas algo do sentido
ancestral do termo era preservado: a diversidade e a
celebração (MOLINA, 2015, p. 107).

Hermilo Borba Filho, Aristóteles Soares, Francisco Pereira da Silva, José Maria Monteiro, João Augusto, Aldo Calvet, Léo Victor, Lúcio Fiúza, Rachel de Queiroz, Antônio Callado, Maria Inês de Almeida e Adolphina Bonapace Portela foram alguns dos dramaturgos que tiveram suas obras divulgadas no Festival do Autor Novo, mesmo que alguns já fossem conhecidos, especialmente fora do Rio de Janeiro, com outras criações montadas anteriormente. O resultado é que, além de ter revelado muitos artistas ao mercado profissional, de acordo com o pesquisador Diego Molina (2015, p. 108), a organização deste festival "teve excelentes resultados devido à boa divulgação dos espetáculos, garantindo sempre uma plateia lotada e dialogando com uma das grandes questões do teatro nacional da época: a busca por uma nova dramaturgia".

\section{TEATRO ATRELADO ÀS OUTRAS ARTES}

No sentido de manifestação cultural organizada, com critérios pré-estabelecidos, prazos a cumprir (por exemplo, no período de inscrição aos participantes, de seleção da programação final e definição de local e data a cada um se exibir), o festival, da ação beneficente no princípio, passou a ser um verdadeiro culto às artes, oferecidas e consumidas em doses maiores num período de dedicação quase exclusiva à fruição (vide programação, muitas vezes, nos três turnos diários). Foi partindo desta perspectiva que, financiado pelo projeto de Lei 826, o Festival do Rio de Janeiro, concebido pela Comissão Artística e Cultural do Theatro Municipal do Rio de Janeiro, surgiu em 1952 para reunir ali diversas manifestações de arte.

Sua estreia se deu com vários concertos musicais, bailados, óperas e participação de espetáculos de comédia liderados por Silveira Sampaio, na sátira escrita e dirigida pelo próprio artista, Deu Freud Contra; e Procópio Ferreira, junto à sua Companhia, com obras como O Demônio Familiar, de José Alencar, e Essa Mulher é Minha, de Raymundo Magalhães Júnior, entre outras; além do Teatro de Arte do Rio de Janeiro, com a peça Já é Manhã no Mar, de Maria Jacintha (dir. Ribeiro Fortes). O sucesso foi tanto que, em 1953, cogitou-se a realização do Festival do Teatro Brasileiro, ideia da atriz e diretora Bibi Ferreira quando esteve à frente da direção brasileira daquele suntuoso teatro, contratada como técnica de espetáculos declamados e responsável pela programação nacional a ser ali apresentada.

Depois de longo tempo organizando o vasto programa de festividades, ela viu frustradas as suas ideias, quase todas não aprovadas pela Comissão Artística e Cultural daquela casa de espetáculos, 
e só conseguiu realizar parte da programação da segunda edição do Festival do Rio de Janeiro. Tudo se resumiu a sessões de três peças diferentes num único programa que ela dirigiu, entre novembro e dezembro de 1953, sendo duas do dramaturgo Roberto Gomes, Casa Fechada e Sonho de Uma Noite de Luar (nesta última, Bibi Ferreira atuava também, ao lado de Paulo Porto), e outra do português Júlio Dantas, A Ceia dos Cardeais (com os consagrados atores Jayme Costa, João Villaret e Sérgio Cardoso no elenco).

A programação do festival carioca começou em outubro, com recitais poéticos e musicais, óperas, bailados, concertos sinfônicos, conferências, exibição folclórica e uma temporada de peças que incluía a tragicomédia As Bruxas já Foram Meninas, de José César Borba (dir. Esther Leão), pela Cia. Sarah-José César Borba, antecipada pelo monólogo Antes do Café, de Eugene O'Neill, com a aclamada atriz paulistana Madalena Nicol. Pouco depois, houve até uma "Festa de Confraternização da Família Teatral", com 15 grandes artistas exibindo-se, nomes como Grande Otelo e Henriette Morineau, em meio a jovens integrantes do Teatro do Estudante do Brasil, além da comemoração dos 40 anos de palco da artista portuguesa radicada no Brasil, Sarah Nobre, na comédia O Buquê, de Meilhac e Halévy.

Por último, subiu ao palco do Theatro Municipal do Rio de Janeiro a encenação de Hécuba, de Eurípedes, tendo intérpretes do TEB no elenco principal (dir. cênica Carlos Marchese e dir. geral Paschoal Carlos Magno), com participação do Conjunto Orquestral Francisco Braga (dir. musical Maria Joppert), com músicas do maestro Francisco Mignone e danças assinadas pelo coreógrafo tcheco Vaslav Veltchek, e mais 120 jovens estudantes na figuração. Exibida algumas vezes, inclusive em vesperais, a grandiosa montagem encerrou a programação do Festival do Rio de Janeiro de 1953. Ainda assim, Bibi Ferreira não conseguiu superar a decepção que enfrentou pela não concretização dos seus sonhos iniciais e acabou pedindo demissão à Municipalidade do cargo que ocupava. Enfrentando problemas financeiros muitas vezes, o Festival do Rio de Janeiro prosseguiu até o ano de 1964, mas cada vez mais dando prioridade à participação dos segmentos da música e do ballet clássico profissionais.

\section{ESPAÇO DE APRENDIZADO E DE REUNIÃO DO TEATRO QUE SE FAZ}

Reforçando laços maiores entre a arte, seus fazedores e a sociedade, um festival nasce para tornar a arte cada vez mais reconhecida, disseminada, apreciada e legitimada em sua importância como produto a ser consumido. Por isso, sob patrocínio da Comissão do IV Centenário da Cidade de São Paulo, em 1954, um novo evento no Brasil foi programado com perfil parecido com aquele pioneiro Festival Shakespeare de Paschoal Carlos Magno: o Festival Martins Pena, agora valorizando a "prata da casa". Como primeira comemoração oficial de teatro no estado paulistano e celebrando um autor nacional, a realização foi entregue à Escola de Arte Dramática (EAD), ou seja, mais uma vez com atores-alunos nos elencos.

Três espetáculos foram apresentados no Teatro Leopoldo Fróes: a comédia Os Dous ou O Inglês Maquinista (dir. Luís de Lima); a tragifarsa $O$ Diletante e a comédia A Família e a Festa na Roça (dir. Alfredo Mesquita), cada um em um ato, com ingressos populares, no período de 3 a 11 de abril de 1954 (já que a sessão do dia 2 teve que ser cancelada), mas nem sempre atraindo bom público no início. Como aluno, Jorge Andrade, dramaturgo que ganharia projeção nacional mais à frente com $A$ Moratória, estava no elenco de alguns daqueles trabalhos.

O Festival Martins Pena deu tão certo, que ganhou repetição no grande auditório do Teatro de Cultura Artística; fez parte da excursão artística da EAD à Belo Horizonte; e pôde ser retomado no Teatro João Caetano, agora com ingressos gratuitos. Em 1955, quando o jornal O Estado de S. Paulo realizou a entrega dos prêmios "Saci" aos Melhores do Cinema e Teatro brasileiros em 1954, a comissão julgadora deu o Prêmio Especial de Teatro à EAD. A partir daí, não foram poucos os festivais de teatro que reuniam textos de um mesmo dramaturgo por todo o país, nacional ou estrangeiro.

Se festival passou a ser sinônimo de reverência a um autor dramático ou espaço de aprendizado e exercício para alunos, foi em São Paulo que a ideia chegou mais próxima do perfil que conhecemos hoje. Promovido pelo Clube de Teatro, sob a presidência de Nicolau Cinelli, com a colaboração da Federação Paulista de Amadores Teatrais 
e prevendo acontecer anualmente a partir de então, com direito a prêmios aos melhores e júri composto por cinco membros indicados pela Associação Brasileira de Críticos Teatrais - Seção de São Paulo, o I Festival Paulista de Teatro Amador aconteceu de 6 a 22 de novembro de 1954, dando o pontapé para a série de festivais artísticos com variadas atrações que surgiriam em todos os cantos do Brasil ${ }^{1}$.

O evento, cuja finalidade era "estreitar as relações entre os grupos amadores teatrais, proporcionandoIhes a oportunidade de apresentar os resultados de seus trabalhos e de estudar e debater, em conjunto, os problemas do teatro amador" (NIMTZOVITCH, Correio Paulistano, 14 set. 1954, p. 07), ocupou o Teatro Colombo, cedido com isenção das taxas municipais pela Secretaria de Educação e Cultura de São Paulo, e com uma única peça sendo levada, excepcionalmente, no Teatro João Caetano. A iniciativa precedeu de poucos dias o I Congresso Paulista de Teatro Amador, que aconteceu de 25 a 28 de novembro daquele ano, no grande auditório do Museu de Arte Moderna, encerrando com a entrega do troféu "Arlequim" aos melhores do Festival.

No Congresso, participaram representantes dos grupos amadores e autoridades convidadas, com a programação dedicada a discutir "vários temas de grande interesse, tais como o conceito de teatro amador, as relações do teatro amador e profissional, o auxílio dos poderes públicos, o direito autoral e o teatro amador, o ensino do teatro no Brasil, o repertório do teatro amador, o teatro amador e a crítica, além de outros" (GARCIA, 2006, p. 243). Para concretizar financeiramente o Festival, já que não se contou com apoio nenhum neste sentido, foi promovido um concurso para a escolha da Rainha do Teatro Amador de 1954, cujos votos para as candidatas eram vendidos.

Qualquer equipe amadora pôde se inscrever no Festival, desde que filiada à Federação Paulista de Amadores Teatrais, com apenas um trabalho em drama ou comédia, de autor brasileiro ou estrangeiro (com apresentação no idioma nacional) e respeitando as restrições impostas pelo Departamento de Diversões Públicas da Secretaria de Segurança Pública. Os crítérios para a seleção levaram em conta o tempo de existência do grupo, o número de espetáculos já feitos, o repertório apresentado e as referências da crítica escrita, dados que deviam constar anexados no formulário de inscrição, além de três cópias datilografadas ou impressas da peça a ser representada e a autorização dos pais ou responsáveis aos menores de 18 anos. Ninguém podia participar de dois grupos distintos na mesma categoria.

Os selecionados tiveram que pagar taxa de inscrição no valor de 1 mil cruzeiros, recebendo cem ingressos para venda "quase obrigatória" (a dez cruzeiros cada um), não sendo permitida qualquer tipo de remuneração. No entanto, a entrada para as atrações era franca. Com representação regional, participaram do I Festival Paulista de Teatro Amador 15 espetáculos, entre altos e baixos na qualidade. A maioria das obras era de autores estrangeiros, e apenas uma, entre os autores nacionais, direcionada ao público infantil: A Menina das Nuvens, do Grupo Experimental de Teatro, que inclusive recebeu Prêmio Especial pela direção e cenografia, ambas de Francisco Giachie. O Quadro 1 a seguir traz detalhes de toda a programação:

Ao final, 12 categorias distintas foram premiadas: Melhor Espetáculo (D. Rosita, da EAD), com o prêmio "Arlequim", além de medalhas de prata e diplomas a cada integrante; Melhor Diretor, Atriz e Ator de Drama e de Comédia (sendo que os intérpretes ganharam bolsa de estudos para cursos na EAD), Melhor Coadjuvante Masculino e Feminina, Melhor Cenógrafo, Melhor Figurinista e aquele Prêmio Especial, cada qual com medalha de prata e diploma. A comissão julgadora foi composta pelos críticos Décio de Almeida Prado, Maria José de Carvalho, Athos Abramo, Guarani Edu Gallo e Oscar Nimtzovitch. O evento marcou tanto que, ao realizar retrospectiva do setor amadorístico paulistano, o crítico Clóvis Garcia (2006, p. 243) considerou o I Festival Paulista de Teatro Amador o fato mais importante do movimento teatral de 1954, "um marco no desenvolvimento da arte cênica entre nós".

Com o sucesso da primeira edição do festival, em 1955, na segunda edição, o festival recebeu inscrição de 40 peças. E a partir da terceira edição, os espetáculos premiados realizaram temporada no Teatro Leopoldo Fróes, uma semana cada. [...] A FPAT [Federação Paulista de Teatro Amador], como órgão de coesão dos grupos amadores do estado de São Paulo, ajudou a fortalecer essa categoria de teatro e, principalmente, com o festival, deu-Ihe 
Quadro 1 - I Festival Paulista de Teatro Amador - De 6 a 22 de novembro de 1954, no Teatro Colombo e Teatro João Caetano (São Paulo/SP).*

\begin{tabular}{|c|c|c|c|}
\hline Atração & Espetáculo & Autoria & Direção \\
\hline $\begin{array}{l}\text { Escola de Arte } \\
\text { Dramática de São } \\
\text { Paulo }\end{array}$ & D. Rosita & Federico García Lorca & Alfredo Mesquita \\
\hline $\begin{array}{l}\text { Grupo Teatral do } \\
\text { Jardim América - Conf. } \\
\text { das Famílias Cristãs }\end{array}$ & O Homem e as Armas & Bernard Shaw & Evaristo Ribeiro \\
\hline $\begin{array}{l}\text { Sociedade dos Artistas } \\
\text { Independentes }\end{array}$ & Antígone & Jean Anouilh & Osvaldo Pisani \\
\hline $\begin{array}{l}\text { Teatro Escola do Clube } \\
\text { A. Santista }\end{array}$ & $\begin{array}{l}\text { Uma Mulher Que Veio } \\
\text { de Londres }\end{array}$ & $\begin{array}{l}\text { Munhoz Secca, trad. } \\
\text { Joaquim d'Almada }\end{array}$ & Não divulgada \\
\hline $\begin{array}{l}\text { Grupo Teatral do } \\
\text { Grêmio Politécnico }\end{array}$ & Nossa Cidade & Thorton Wilder & João E. Coelho Netto \\
\hline Teatro Lotte Sievers & Capricho Medieval & $\begin{array}{l}\text { Alejandro Casona } \\
\text { (quatro farsas) }\end{array}$ & Sérgio Britto \\
\hline $\begin{array}{l}\text { Teatro Escola do SESI e } \\
\text { Teatro da Amizade }\end{array}$ & $\begin{array}{l}\text { O Ouro Que Deus dá e } \\
\text { Nos Braços de Morfeu }\end{array}$ & $\begin{array}{l}\text { Luiz Francisco Rebello } \\
\text { e Hortência Rodrigues }\end{array}$ & Não divulgada \\
\hline $\begin{array}{l}\text { Grupo Teatral XI de } \\
\text { Agosto }\end{array}$ & $\begin{array}{l}\text { Corrupção no Palácio } \\
\text { da Justiça }\end{array}$ & Ugo Betti & Evaristo Ribeiro \\
\hline $\begin{array}{l}\text { Clube de Teatro (elenco } \\
\text { "A") }\end{array}$ & o Coração Delator & $\begin{array}{l}\text { Edgar Allan Poe, } \\
\text { adaptação Graça Mello }\end{array}$ & Vicente Acedo \\
\hline $\begin{array}{l}\text { Grupo de Teatro } \\
\text { do Grêmio Caixa } \\
\text { Econômica Federal }\end{array}$ & $\begin{array}{l}\text { Guerras do Alecrim e } \\
\text { da Manjerona }\end{array}$ & $\begin{array}{l}\text { Antônio José da Silva, } \\
\text { o Judeu }\end{array}$ & Osmar Rodrigues Cruz \\
\hline $\begin{array}{l}\text { Amadores Reunidos de } \\
\text { Teatro }\end{array}$ & O Fim & Boris Fetchir & Boris Fetchir \\
\hline $\begin{array}{l}\text { Grupo Cênico da } \\
\text { Associação dos } \\
\text { Cabeleireiros de São Paulo }\end{array}$ & $\begin{array}{l}\text { Os Inimigos Não } \\
\text { Mandam Flores }\end{array}$ & Pedro Bloch & Luiz Sobrinho \\
\hline $\begin{array}{l}\text { Teatro Experimental } \\
\text { do Negro de São Paulo }\end{array}$ & O Santo e o Cavalo & Augusto Boal & $\begin{array}{l}\text { Geraldo Campos de } \\
\text { Oliveira }\end{array}$ \\
\hline $\begin{array}{l}\text { Grupo Experimental } \\
\text { de Teatro }\end{array}$ & A Menina das Nuvens & Lúcia Benedetti & Francisco Giachie \\
\hline
\end{tabular}


evidência e fomento com as premiações, porque muitos grupos montavam suas peças voltadas para esse festival, entre outros que passaram a ser promovidos (ROSA, 2008, p. 31-32).

Nos mesmos moldes da primeira edição, o Festival Paulista de Teatro Amador seguiu anualmente, agora contando com os auspícios da Comissão Estadual de Teatro, até 1959, tudo indicando que foi interrompido, mudou de nome e só retomado em 1962. Além de ter contado com muitos talentos em início de carreira, a exemplo de Gianfrancesco Guarnieri, Miriam Mehler, Milton Andrade, Nelson Xavier, Francisco Cuoco, Yara Amaral, Oduvaldo Vianna Filho e Leônidas Hegenberg, o evento provou que o interesse pelo teatro não se limitava apenas à capital paulista, mas, também, se estendia a outros municípios como Ourinhos, Rio Claro e Marília, dando estímulo, inclusive, ainda naquela década de 1950, ao surgimento de outros festivais nas cidades de Santos, Sorocaba, Bauru, São José dos Campos e Campinas, inicialmente.

\section{O BRASIL QUE SE VÊ}

Ainda que delimitado a um momento específico, eventual, um festival pode passar como um (e) vento apenas, ou não, marcar profundamente aqueles que o prestigiaram e até modificar perspectivas e práticas a partir de então. Por isso é o momento oportuno de aprendizado e renovação de repertório, de se alargar fronteiras, onde se espera exercitar o olhar crítico, refletir prática e teoricamente, favorecer o estudo minucioso de cada elemento teatral, compartilhar processos de trabalho, experimentar-se nas aulas programadas, confraternizar com os seus - ainda que muitas vezes a competição não esteja de todo esquecida -, celebrar a diversidade, as diferenças, mas espaço também para difundir reivindicações, especialmente junto ao Poder Público.

Marcelo Bones (2017), mentor e um dos realizadores do Observatório dos Festivais, organização voltada para a pesquisa, informação e reflexão sobre os festivais de teatro no Brasil $^{2}$, além de destacar o papel fundamental desempenhado pelos mesmos na circulação de espetáculos, aponta outras ramificações consideráveis de todos eles, lembrando que são elos fundamentais na cadeia de circulação e fruição da produção teatral; espaços privilegiados de inovação e difusão de vanguarda artística; têm forte capacidade de formação de profissionais técnicos e artísticos e cumprem função importante na formação de público e plateias, além do impacto econômico que causam na cadeia produtiva da cultura no território onde acontecem.

Mas naquele final da década de 1950 faltava, ainda, ao Brasil um festival de teatro de caráter nacional. Foi por iniciativa da atriz, diretora e empresária Dulcina de Moraes que o Rio de Janeiro serviu de sede para o I Festival de Amadores Nacionais, de 15 de janeiro a 12 de fevereiro de 1957, patrocinado pela instituição que ela criara, a Fundação Brasileira de Teatro (FBT), no Teatro Dulcina, com inscrições abertas para conjuntos de Norte a Sul do país. Ao justificar a existência da entidade e, consequentemente, a promoção daquele festival, uma de suas mais frutíferas ações, Dulcina de Moraes, que apreciava o idealismo dos amadores, segmento que para ela "ocupava o lugar das Escolas Dramáticas não existentes" (apud VIOTTI, 2000, p. 456), deu o seguinte depoimento:

\footnotetext{
Há, não só no Rio ou em São Paulo, mas pelo Brasil afora, um entusiasmo tão grande pelo teatro que até parece "moda". Todo mundo quer fazer teatro. Em qualquer pequena cidade encontra-se um conjunto de amadores. Em face deste grande interesse pela arte da ribalta também por parte do público, impõe-se, neste momento, a organização (e com urgência) de uma entidade capaz de coligar todos aqueles que estiverem, de um modo ou de outro, trabalhando pelo teatro. Apoiados neste fenômeno é que fundamos a FBT (da qual sou presidente), e cuja finalidade principal é orientar principalmente os grupos amadores, dando a estes toda a assistência necessária para um perfeito desenvolvimento dos mesmos e divulgar a arte cênica em geral (MORAES apud VIOTTI, 2000, p. 454).
}

Em sua primeira e única edição, o evento foi pioneiro por reunir atrações de várias partes do Brasil, com a participação de conjuntos teatrais de 10 estados diferentes (Rio de Janeiro, São Paulo, Minas Gerais, Paraná, Rio Grande do Sul, Bahia, Pernambuco, Alagoas, Sergipe e Pará). Grupos confirmados de Santa Catarina, Maranhão e Amapá, estranhamente não chegaram a se apresentar. O Festival chamou atenção também pelo ineditismo de alguns dos textos nunca antes vistos na capital carioca, de dramaturgos estrangeiros até nacionais. O Quadro 2 a seguir contém detalhes da grade completa: 
Com entrada sempre franca, no intuito de preparar novas plateias, a intenção era premiar os três melhores espetáculos com medalhas. O resultado foi mais do que satisfatório aos pernambucanos: a peça $A$ Compadecida, texto do dramaturgo ainda quase desconhecido nacionalmente, Ariano Suassuna, pelo grupo Teatro Adolescente do Recife (dir. Clênio Wanderley), ganhou a Medalha de Ouro como Melhor Espetáculo do evento numa ovação unânime. A Medalha de Prata ficou com a Federação Baiana dos Teatros Amadores apresentando uma tragédia nordestina de outro pernambucano, A Grande Estiagem, de Isaac Gondim Filho (dir. Clênio Wanderley, consagrando-se duplamente). A Medalha de Bronze coube ao Teatro Rural do Estudante, de Campo Grande, área rural do Rio de Janeiro, com A Almanjarra, de Arthur Azevedo (dir. Mário de Almeida). A comissão julgadora era formada por mais de uma dúzia de membros, de críticos a professores de teatro.

Durante o evento, que festejou a vitória do autor nacional, vale notar, todos os 19 grupos participantes puderam aproveitar um Curso Intensivo de Teatro, totalmente gratuito, promovido pela Academia de Teatro da Fundação Brasileira de Teatro, com 4 horas de aulas diárias de interpretação (com as professoras Dulcina de Moraes e Henriette Morineau), dicção e impostação da voz (com Lília Nunes) e história do teatro (com os professores Junito de Souza Brandão e José Paulo Moreira da Fonseca), além de terem passagens viabilizadas e estadias pagas pela FBT. Paschoal Carlos Magno foi o homenageado do todo o certame.

Diante do sucesso do Festival, mesmo com algumas críticas ferinas à figura de Dulcina de Moraes, a Fundação Brasileira de Teatro cogitou a realização de um novo evento em 1958, de âmbito maior, sul-americano, mas ficou só no desejo. Por indicação de vários críticos, A Compadecida, que deu notoriedade internacional ao autor Ariano Suassuna a partir de então, foi repetida nos dias 13 e 14 de fevereiro de 1957, no mesmo palco do Teatro Dulcina, patrocinada pela Sociedade Teatro de Arte, com convites distribuídos aos seus sócios. O sucesso da peça fez ainda com que a Fundação Brasileira de Teatro garantisse novas apresentações do grupo ao público em geral, de 15 a 17 daquele mês. E, desde então, João Grilo e
Chicó passaram a ser conhecidos e levados à cena em todo o Brasil, com a peça ganhando versões, inclusive, no estrangeiro.

Da parte do "Norte" do país, como ainda era chamada a região que hoje são o Nordeste e Norte brasileiros, o pioneiro festival de teatro aconteceu dois anos antes, na cidade do Natal, no Rio Grande do Norte, quando o teatrólogo Meira Pires, então diretor do Teatro Carlos Gomes (hoje Teatro Alberto Maranhão), resolveu encarar a realização do competitivo I Festival Nortista de Teatro Amador, de 10 a 18 de setembro de 1955, com uma semana bem movimentada de peças do Rio Grande do Norte, Ceará, Alagoas, Bahia, Paraíba e Pernambuco, além de palestras e mesas-redondas sobre os vários problemas que afligiam os amadores teatrais nordestinos naquele momento (nem tão diferentes dos tempos de hoje). Entre os temas discutidos, o ensaiador categorizado, a posição do Serviço Nacional de Teatro, as peças nacionais e estrangeiras, impostos e taxas, as bibliotecas especializadas e o intercâmbio artístico.

Das palestras programadas, Isaac Gondim Filho abordou o "Teatro no Nordeste"; o antropólogo Câmara Cascudo falou sobre "O gesto no teatro"; Valdemar de Oliveira tratou do "Teatro escolar"; e o cônsul Carlos Lamas trouxe dados do "Teatro no Chile". Quanto aos espetáculos, somente com obras adultas, o Prêmio de Melhor Conjunto, em caráter hors concours, foi para o Teatro de Amadores de Pernambuco, com Está lá Fora um Inspetor, de J. B. Priestley (dir. Valdemar de Oliveira); a Medalha de Prata de Melhor Direção para Willy Keller, por Os Inimigos Não Mandam Flores, de Pedro Bloch, pelo Teatro de Amadores de Maceió; e a Medalha de Ouro de Melhor Direção ficou com Alfredo de Oliveira, por sua condução em Massacre, de Emmanuel Roblès, com o Teatro de Cultura da Bahia, entre outros destaques. 0 Quadro 3 a seguir revela a programação completa do evento:

Da parte da imprensa - a Associação dos Cronistas Teatrais de Pernambuco (ACTP), entidade recifense que reunia jornalistas que se dedicavam a escrever sobre o teatro, foi representada por vários associados, assim como a Gazeta de Alagoas, que enviou o repórter Luiz Guttemberg -, começou ali a cobertura dos festivais teatrais. 
Quadro 2 - I Festival de Amadores Nacionais - De 15 de janeiro a 12 de fevereiro de 1957, no Teatro Dulcina (Rio de Janeiro/RJ)*

\begin{tabular}{|c|c|c|c|}
\hline Atração & Espetáculo & Autoria & Direção \\
\hline $\begin{array}{l}\text { Teatro Adolescente do } \\
\text { Recife, do Recife/PE }\end{array}$ & A Compadecida & Ariano Suassuna & Clênio Wanderley \\
\hline $\begin{array}{l}\text { Fed. Baiana dos } \\
\text { Teatros Amadores, de } \\
\text { Salvador/BA }\end{array}$ & A Grande Estiagem & Isaac Gondim Filho & Clênio Wanderley \\
\hline $\begin{array}{l}\text { Teatro Rural do Estudante, } \\
\text { de Campo Grande, área } \\
\text { rural do Rio de Janeiro/RJ }\end{array}$ & A Almanjarra & Arthur Azevedo & Mário de Almeida \\
\hline $\begin{array}{l}\text { Teatro Operário } \\
\text { do SESI, de Belo } \\
\text { Horizonte/MG }\end{array}$ & O Noviço & Martins Pena & João Ceschiatti \\
\hline $\begin{array}{l}\text { Grupo dos } 16 \text {, de Porto } \\
\text { Alegre/RS }\end{array}$ & laiá Boneca & Ernani Fornari & Reynaldo Ivo Daudt \\
\hline $\begin{array}{l}\text { Dep. de Teatro da } \\
\text { Associação Atlética } \\
\text { Matarazzo, de São } \\
\text { Paulo/SP }\end{array}$ & Uma Casa de Bonecas & Henrik Ibsen & $\begin{array}{l}\text { Vicente Eduardo } \\
\text { Scrivano }\end{array}$ \\
\hline $\begin{array}{l}\text { Os Intérpretes, do Rio } \\
\text { de Janeiro/RJ }\end{array}$ & Mortos Sem Sepultura & Jean-Paul Sartre & Isaac Bardavid \\
\hline $\begin{array}{l}\text { Grupo Cênico dos Ex- } \\
\text { Alunos do Colégio Dom } \\
\text { Bosco, de Belém/PA }\end{array}$ & Os Mortos Voltam & Hercílio Renóglio & Paulo de Almeida Brasil \\
\hline $\begin{array}{l}\text { Os Novos, de Belém/ } \\
\text { PA }\end{array}$ & No Poço do Falcão & W. B. Yeats & Margarida Schivazappa \\
\hline $\begin{array}{l}\text { Teatro de Amadores de } \\
\text { Sergipe, de Aracaju/ } \\
\text { SE }\end{array}$ & Ladra & Silvino Lopes & João Costa \\
\hline $\begin{array}{l}\text { Teatro Universitário, } \\
\text { da União Estadual de } \\
\text { Estudantes, de Porto } \\
\text { Alegre/RS }\end{array}$ & À Margem da Vida & Tennessee Williams & Antônio Abujamra \\
\hline $\begin{array}{l}\text { Teatro do Estudante do } \\
\text { Paraná, de Curitiba/PR }\end{array}$ & $\begin{array}{l}\text { Uma Autora em Busca } \\
\text { de Personagens }\end{array}$ & Didi Fonseca & Armando Maranhão \\
\hline $\begin{array}{l}\text { Teatro de Cultura da } \\
\text { Bahia, de Salvador/BA }\end{array}$ & O Sorriso de Gioconda & Aldous Huxley & Alfredo de Oliveira \\
\hline $\begin{array}{l}\text { Teatro da Mocidade, } \\
\text { de São Paulo/SP }\end{array}$ & $\begin{array}{l}\text { A Mão do Macaco e } \\
\text { Alô, ó de Fora }\end{array}$ & $\begin{array}{l}\text { W. W. Jacobs e William } \\
\text { Saroyan }\end{array}$ & Egídio Eccio \\
\hline
\end{tabular}




\begin{tabular}{|c|c|c|c|}
\hline $\begin{array}{l}\text { Teatro de Amadores de } \\
\text { Sergipe, de Aracaju/ } \\
\text { SE }\end{array}$ & Ladra & Silvino Lopes & João Costa \\
\hline $\begin{array}{l}\text { Teatro Universitário, } \\
\text { da União Estadual de } \\
\text { Estudantes, de Porto } \\
\text { Alegre/RS }\end{array}$ & À Margem da Vida & Tennessee Williams & Antônio Abujamra \\
\hline $\begin{array}{l}\text { Teatro do Estudante do } \\
\text { Paraná, de Curitiba/PR }\end{array}$ & $\begin{array}{l}\text { Uma Autora em Busca } \\
\text { de Personagens }\end{array}$ & Didi Fonseca & Armando Maranhão \\
\hline $\begin{array}{l}\text { Teatro de Cultura da } \\
\text { Bahia, de Salvador/BA }\end{array}$ & O Sorriso de Gioconda & Aldous Huxley & Alfredo de Oliveira \\
\hline $\begin{array}{l}\text { Teatro da Mocidade, } \\
\text { de São Paulo/SP }\end{array}$ & $\begin{array}{l}\text { A Mão do Macaco e } \\
\text { Alô, ó de Fora }\end{array}$ & $\begin{array}{l}\text { W. W. Jacobs e William } \\
\text { Saroyan }\end{array}$ & Egídio Eccio \\
\hline
\end{tabular}

Isaac Gondim Filho, para sua coluna do Diario de Pernambuco, por exemplo, escreveu dez crônicas diferentes, detalhando as peças e culminando ainda com dois outros textos avaliativos do evento. Independente de críticas surgidas, o I Festival Nortista de Teatro Amador foi um sucesso e os participantes se reuniram para deliberar que conclusões o certame trazia, solicitando o apoio necessário para a continuidade da atividade teatral no Nordeste por parte do poder público, da imprensa e da sociedade em geral.

E já que um festival de teatro é também espaço para difundir reivindicações, especialmente junto aos Governos, Valdemar de Oliveira, o crítico de artes W., em dura escrita no Jornal do Commercio (25 set. 1955 , p. 6), não poupou o SNT, "de pé firme contra tudo quanto cheira a amador", pelo total descaso que dava ao que acontecia no teatro para além do Rio de Janeiro. Afirmou ele que a instituição federal tinha negado toda assistência financeira, moral ou técnica ao Festival e que nem mesmo o seu diretor, o jornalista integralista Adonias Aguiar Filho, havia dado o ar da graça no evento:

O Serviço Nacional de Teatro fez questão de consagrar-se, ostensivamente, Serviço Carioca

\begin{abstract}
de Teatro [grifo meu]. Não deu bola. Seria até o caso de pensar-se num Serviço Nortista de Teatro, a funcionar no Recife, com verbas fornecidas pelos governos estaduais do Norte, e destinado a amparar o que desamparadamente vive de toda a atenção e de todo o interesse dos poderes públicos federais. Mas, vive, sobrevive e triunfa, é o que temos a dizer a esses gordos senhores: sem eles ou contra eles (W. [Valdemar de Oliveira], Jornal do Commercio, 25 set. 1955, p. 06).
\end{abstract}

Medeiros Cavalcanti, outro combativo jornalista, aprovou a ideia e reforçou no Jornal do Commercio (27 set. 1955, p. 06) que o I Festival Nortista de Teatro Amador tinha ousado "ir para diante sem o auxílio do birôzinho carioca. Foi uma realidade tangível, proveitosa, única na história do Teatro Brasileiro", isto se levarmos em conta ser este o primeiro festival que conseguiu agregar agentes culturais de vários estados brasileiros. Na mesma resenha, ele defendeu também um "Serviço Nortista de Teatro", mesmo que a medida implicase numa separação ou parecesse um excesso regional. "Mas o fato é que de há muito estamos cindidos e quanto a regionalismos, o nosso tem sido sempre ignorado e até ridicularizado!", justificou. 
Quadro 3 - I Festival Nortista de Teatro Amador - De 10 a 18 de setembro de 1955, no Teatro Carlos Gomes [hoje Teatro Alberto Maranhão] (Natal/RN)

\begin{tabular}{|c|c|c|c|}
\hline Atração & Espetáculo & Autoria & Direção \\
\hline $\begin{array}{l}\text { Teatro do Estudante da } \\
\text { Associação Potiguar de } \\
\text { Estudantes, do Natal/ } \\
\text { RN }\end{array}$ & Além do Horizonte & Eugene O'Neill & José Maria Guilherme \\
\hline $\begin{array}{l}\text { Teatro de Cultura da } \\
\text { Bahia, de Salvador/BA }\end{array}$ & Massacre & Emmanuel Roblès & Alfredo de Oliveira \\
\hline $\begin{array}{l}\text { Teatro do Estudante } \\
\text { da Paraíba, de João } \\
\text { Pessoa/PB }\end{array}$ & Festim Diabólico & Patrick Hamilton & Joel Pontes \\
\hline $\begin{array}{l}\text { Teatro de Amadores de } \\
\text { Maceió, de Maceió/AL }\end{array}$ & $\begin{array}{l}\text { Os Inimigos Não } \\
\text { Mandam Flores }\end{array}$ & Pedro Bloch & Willy Keller \\
\hline $\begin{array}{l}\text { Teatro de Amadores de } \\
\text { Natal, do Natal/RN }\end{array}$ & A Grande Estiagem & Isaac Gondim Filho & Sandoval Wanderley \\
\hline $\begin{array}{l}\text { Grêmio Dramático } \\
\text { Familiar da Bahia, de } \\
\text { Salvador/BA }\end{array}$ & Almas Que Sofrem & $\begin{array}{l}\text { Weldron Americano da } \\
\text { Costa }\end{array}$ & $\begin{array}{l}\text { Weldron Americano da } \\
\text { Costa }\end{array}$ \\
\hline $\begin{array}{l}\text { Teatro Escola do } \\
\text { Ceará, de Fortaleza/ } \\
\text { CE }\end{array}$ & Os Deserdados & Eduardo Campos & Nadir Saboya \\
\hline $\begin{array}{l}\text { Teatro de Amadores } \\
\text { de Pernambuco, do } \\
\text { Recife/PE }\end{array}$ & $\begin{array}{l}\text { Está lá Fora um } \\
\text { Inspetor }\end{array}$ & J. B. Priestley & Valdemar de Oliveira \\
\hline $\begin{array}{l}\text { Teatro Escola do } \\
\text { Ceará, de Fortaleza/ } \\
\text { CE }\end{array}$ & A Via Sacra* & Henri Ghéon & Nadir Saboya \\
\hline
\end{tabular}

* Espetáculo integrado como "programa extra" do Festival, excepcionalmente apresentado no Ginásio Sílvio Pedrosa. O Pequeno Teatro do Nordeste, do Recife, foi o único grupo convidado ausente.

Para piorar tamanho desgosto com o SNT, dois dias após sua crítica ferrenha, Valdemar de Oliveira, ainda sob a inicial W., divulgou o resultado dos conjuntos contemplados com subvenção pela entidade em 1955. "Foram excluídos todos os grupos amadoristas, salvo quatro ou cinco que consta não cobrarem ingressos", foi o que revelou no Jornal do Commercio (27 set. 1955, p. 06). Entre os aprovados estavam companhias como as de Bibi Ferreira (100 mil cruzeiros),
Barreto Júnior (do Recife e de perfil profissional), Ítalo Cúrcio (cada qual com 35 mil cruzeiros) e Raul Levy-Nair Ferreira (30 mil cruzeiros). Talvez pelas inúmeras bordoadas, o Serviço Nacional de Teatro acabou sendo um dos patrocinadores do II Festival Nortista de Teatro Amador, que ocupou o Teatro de Santa Isabel, na capital pernambucana, de 12 a 21 de outubro de 1956, com representações de Fortaleza, Natal, João Pessoa, Recife, Maceió e Salvador. 
Somente três anos depois, de 16 a 24 de janeiro de 1959, no Teatro Deodoro, em Maceió, aconteceu - III Festival Nortista de Teatro Amador, com delegações e espetáculos do Ceará, Sergipe, Rio Grande do Norte, Paraíba, Alagoas e Pernambuco. E, em janeiro de 1961, na cidade de Salvador, na Bahia, deu-se a diminuta programação da quarta e última edição do Festival, já desorganizado e com muitos problemas a resolver. Apenas as peças A Hora Marcada, de Isaac Gondim Filho, dirigida pelo autor e representada pelo Teatro de Cultura da Bahia; O Vestido da Estrela Flor, texto e direção de Antonieta Bispo, com o Teatro Espírita da Bahia; e Onde Canta o Sabiá, de Gastão Tojeiro, pelo Teatro de Amadores de Pernambuco (dir. Hermilo Borba Filho), aconteceram, com esta última fazendo grande esforço para chegar até lá.

Fatores variados como as distâncias a enfrentar, a falta de apoio financeiro nos seus lugares de origem e a desarticulação entre os próprios estados, fizeram com que o Festival Nortista de Teatro Amador, infelizmente, desaparecesse. Mas um dos seus frutos, que deu novas esperanças ao setor amadorista, foi a indicação do teatrólogo Meira Pires para diretor do Serviço Nacional de Teatro, algo que aconteceu no ano de 1967, mesmo que por um período curto de tempo, somente até 1968. No entanto, não se pôde fazer muito com o orçamento tão pequeno e o próprio Meira Pires reclamou da "falta de sensibilidade das autoridades para os problemas culturais" e lamentou que a verba disponível não iria refletir as necessidades de desenvolvimento do SNT: "Este somente poderá ser considerado um órgão atuante se forem entregues recursos que permitam a execução do Plano Nacional de Popularização do Teatro" (apud CASTRO, Correio da Manhã, 26 ago. 1967, p. 07).

\section{ENCONTROS E INTERCÂMBIO}

Ainda no objetivo de revelar os primeiros festivais de teatro que aconteceram no nosso país, nenhum ganhou mais projeção que o Festival Nacional de Teatros de Estudantes, sonho acalentado por Paschoal Carlos Magno - sempre ele - que chegou a sete edições, movimentando as cidades-sedes do Recife (1 $1^{a}$ edição/1958), Santos (2a/1959), Brasília (3a/1960), Porto Alegre (4a/1962), Rio de Janeiro (5\%/1968) e Aldeia de Arcozelo, no município carioca de Paty do Alferes (6ª 1971 e $\left.7^{a} / 1975\right)$, em encontros que fortaleceram a união e o intercâmbio dos fazedores de teatro amador e permitiram a expansão deste campo com o desdobramento de inúmeras outras experiências, inclusive junto ao Estado ${ }^{3}$.

O I Festival Nacional de Teatros de Estu $\rightarrow$ dantes aconteceu de 19 a 29 de julho de 1958, no Recife, recebendo mais de 700 artistas amadores de todo o país (inicialmente foram divulgados 26 conjuntos teatrais de 14 estados da Federação, mas alguns cancelaram sua participação), numa iniciativa de Paschoal Carlos Magno com apoio da Presidência da República, do Ministério da Educação e Cultura, da Reitoria da Universidade de Pernambuco e da Associação dos Cronistas Teatrais de Pernambuco (ACTP). 0 evento, sempre com entrada franca, deveria ser inaugurado pelo pre $\rightarrow$ sidente Juscelino Kubitschek, mas quem o representou foi o ministro da Educação e Cultura, Clóvis Salgado, atrasado na abertura oficial por problemas no avião que o transportava.

Na programação, espetáculos a serem vistos nos teatros de Santa Isabel e do Derby, com sessões diárias às 16 e 21 horas, além de entrega de diversos prêmios, uma "Ceia dos Personagens" (ocorrida na residência do casal Enrique Martinez, cônsul da Espanha, em substituição a um projetado baile); conferências, deba $\rightarrow$ tes, cursos e dois iné $\rightarrow$ ditos julgamentos de personagens, os primeiros do gênero ocorridos no país, de "Hamlet" e "Otelo", ambos absolvidos e vividos respectivamente pelos atores Sérgio Cardoso e Paulo Autran, na Faculdade de Direito do Recife. O júri foi formado por intelectuais e a acusação e a defesa feitas por criminalistas nacionalmente conhecidos.

A divulgação do Festival para toda a cidade, no entanto, deixou a desejar, segundo críticas iniciais na imprensa, apesar da dispensa de ponto para os servidores públicos federais e autárquicos, seguindo ato do presidente da República publicado no Diário Oficial. A abertura contou com um coral de 110 vozes, fruto do $1^{\circ}$ Curso Nacional de Música Sacra. Dos espetáculos participantes, uma maioria absoluta de criações nacionais. 0 encerramento se deu com sessão especial de Seis Personagens à Procura de Autor, de Luigi Pirandello (dir. Hermilo Borba Filho), pelo Teatro de Amadores de Pernambuco. Detalhes completos da programação no Quadro 4 a seguir: 
Quadro 4 - I Festival Nacional de Teatros de Estudantes - De 19 a 29 de julho de 1958, no Teatro de Santa Isabel e Teatro do Derby (Recife/PE), entre outros espaços*

\begin{tabular}{|c|c|c|c|}
\hline Atração & Espetáculo & Autoria & Direção \\
\hline $\begin{array}{l}\text { Norte Teatro Escola do } \\
\text { Pará, de Belém/PA }\end{array}$ & Morte e Vida Severina & $\begin{array}{l}\text { João Cabral de Melo } \\
\text { Neto }\end{array}$ & Maria Sylvia Nunes \\
\hline $\begin{array}{l}\text { Agremiação Goiana de } \\
\text { Teatro, de Goiânia/GO }\end{array}$ & $\begin{array}{l}\text { A Canção Dentro do } \\
\text { Pão }\end{array}$ & $\begin{array}{l}\text { Raymundo Magalhães } \\
\text { Júnior }\end{array}$ & Otávio Arantes \\
\hline $\begin{array}{l}\text { Teatro Rural do } \\
\text { Estudante, de Campo } \\
\text { Grande, área rural do } \\
\text { Rio de Janeiro/RJ }\end{array}$ & Zé do Pato & Elza Pinho Osborne & B. de Paiva \\
\hline $\begin{array}{l}\text { Teatro do Estudante de } \\
\text { Sergipe, de Aracaju/ } \\
\text { SE }\end{array}$ & Escola de Ladrões & Severino Uchôa & Severino Uchôa \\
\hline $\begin{array}{l}\text { Conservatório Nacional } \\
\text { de Teatro, do Rio de } \\
\text { Janeiro/RJ }\end{array}$ & Deus Lhe Pague & Joracy Camargo & Orlando Macedo \\
\hline $\begin{array}{l}\text { Teatro Universitário } \\
\text { Cultural do Brasil, do } \\
\text { Rio de Janeiro/RJ }\end{array}$ & A Beata Maria do Egito & Rachel de Queiroz & Orlando Macedo \\
\hline $\begin{array}{l}\text { Teatro do Estudante } \\
\text { da Paraíba, de João } \\
\text { Pessoa/PB }\end{array}$ & Auto de João da Cruz & Ariano Suassuna & Clênio Wanderley \\
\hline $\begin{array}{l}\text { Teatro Adolescente do } \\
\text { Recife, do Recife/PE }\end{array}$ & $\begin{array}{l}\text { O Casamento } \\
\text { Suspeitoso }\end{array}$ & Ariano Suassuna & Clênio Wanderley \\
\hline $\begin{array}{l}\text { Escola de Arte } \\
\text { Dramática, de São } \\
\text { Paulo/SP }\end{array}$ & Teatro Cômico & Goldoni & Olga Navarro \\
\hline $\begin{array}{l}\text { Teatro Universitário } \\
\text { de Pernambuco, do } \\
\text { Recife/PE }\end{array}$ & Medéa & $\begin{array}{l}\text { Adaptação de } \\
\text { Robinson Jeffers } \\
\text { a partir da obra de } \\
\text { Eurípedes }\end{array}$ & Graça Mello \\
\hline $\begin{array}{l}\text { Escola do Teatro } \\
\text { Duse, do Rio de } \\
\text { Janeiro/RJ }\end{array}$ & $\begin{array}{l}\text { A Descoberta do Novo } \\
\text { Mundo }\end{array}$ & $\begin{array}{l}\text { Morvan Lebesque, } \\
\text { inspirado em Lope de } \\
\text { Vega }\end{array}$ & Luís de Lima \\
\hline $\begin{array}{l}\text { Teatro do Estudante do } \\
\text { Paraná, de Curitiba/PR }\end{array}$ & Fora da Barra & Sutton Vanne & Aristides Teixeira \\
\hline $\begin{array}{l}\text { Teatro do Instituto } \\
\text { Tecnológico de } \\
\text { Aeronáutica, de São } \\
\text { José dos Campos/SP }\end{array}$ & $\begin{array}{l}\text { Os Cegos, Um Pedido } \\
\text { de Casamento e } \\
\text { Hiperbeloide }\end{array}$ & $\begin{array}{l}\text { Michel de Ghelderode, } \\
\text { Anton Tchekhov e a } \\
\text { dupla João Bosco de } \\
\text { Siqueira e Luiz Sérgio } \\
\text { Sampaio }\end{array}$ & $\begin{array}{l}\text { Respectivamente, Luiz } \\
\text { Sérgio Sampaio, A. } \\
\text { Bittencourt e a dupla } \\
\text { João Bosco Siqueira e } \\
\text { Luiz Sérgio Sampaio }\end{array}$ \\
\hline
\end{tabular}




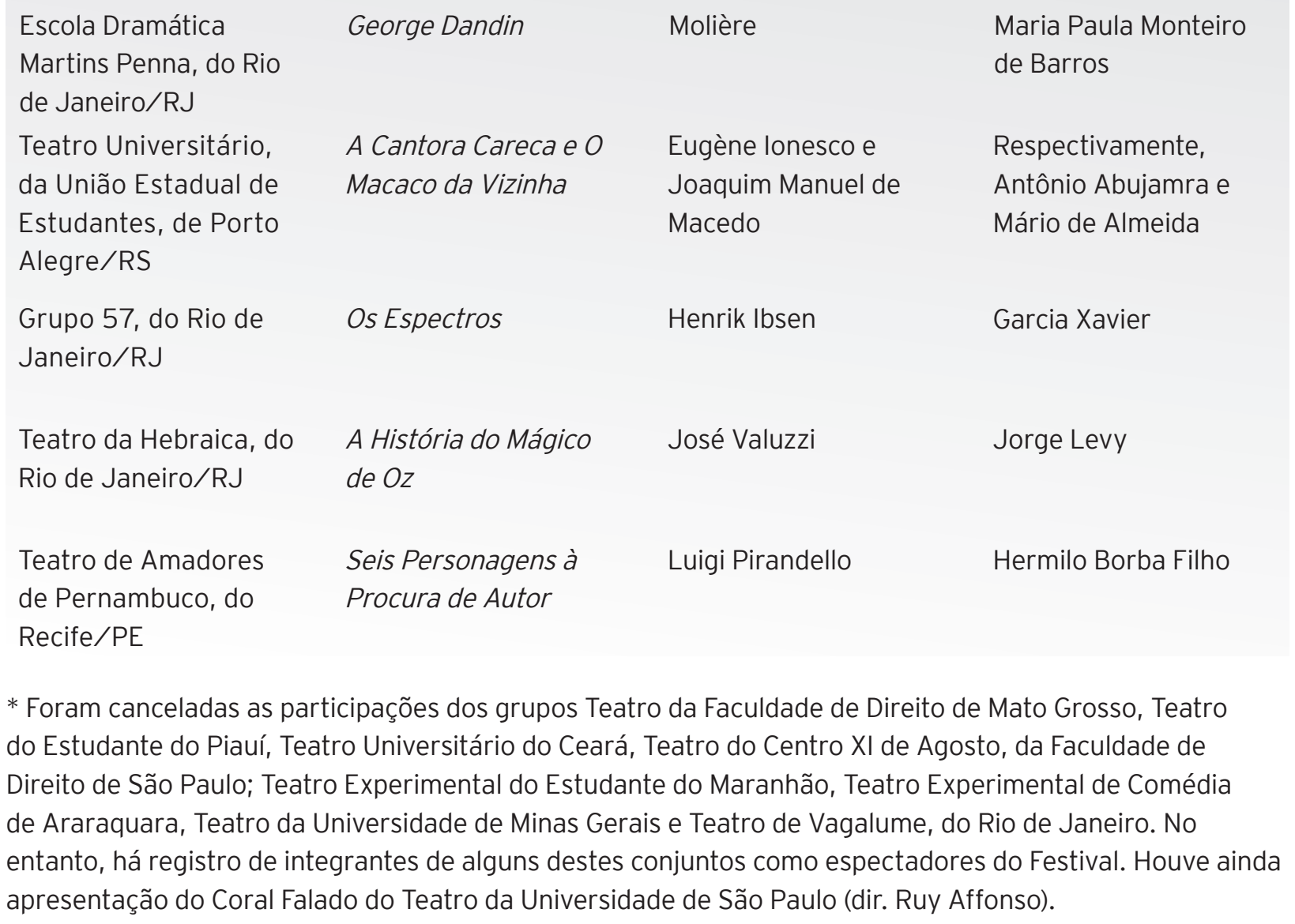

Das atividades formativas, foram programadas conferências-aulas com Luís de Lima, com o tema "A pantomima e a mímica", e Willy Keller, "A representação no teatro grego", e palestras de Enrique Martinez Lopez, sobre o repertório dramático espanhol, e de Joel Pontes abordando a obra de Machado de Assis. Outras palestras puderam ser ministradas por professores da Universidade do Recife e do Teatro Duse, nomes como Hermilo Borba Filho e Luiza Barreto Leite, além de Valdemar de Oliveira. O prêmio destinado ao Melhor Diretor era uma viagem de ida e volta à Europa com direito a bolsa de estudos. Cenas de grande entusiasmo aconteceram quando foram anunciados, no Teatro de Santa Isabel, os premiados do Festival, cujo julgamento foi feito pelos próprios grupos que designaram, cada um, três dos seus componentes para compor o grande júri.

Divididos por região, o Melhor Espetáculo do Norte foi Morte e Vida Severina, do Norte Teatro Escola do Pará, que também levou o prêmio de Melhor Autor Brasileiro para João Cabral de Melo Neto. O Melhor Espetáculo do Sul foi a dobradinha o Macaco da Vizinha e A Cantora Careca (dando o título de $2^{\circ}$ Melhor Diretor Amador para Antônio Abujamra) pelo Teatro Universitário, de Porto Alegre; e o Melhor Espetáculo do Centro foi Zé do Pato, de Elza Pinho Osborne, pelo Teatro Rural do Estudante, de Campo Grande (RJ), com B. de Paiva como Melhor Diretor Amador, ele e Abujamra ganhando viagem de ida e volta à Europa, com bolsa de estudo. Já o Melhor Diretor Profissional foi Olga Navarro, pela peça Teatro Cômico, de Goldoni, pela Escola de Arte Dramática, de São Paulo. Entre os Melhores Intérpretes, nomes como Carlos Miranda, Rogério Fróes, Amélia Bittencourt e Margarida Cardoso.

Segundo matéria de avaliação no Jornal do Commercio, Paschoal Carlos Magno encerrou a solenidade dizendo que "o festival fora mais uma demonstração de interesse e entusiasmo que os estudantes dedicam ao teatro, congratulando-se também com a ordem e disciplina que imperou em toda a sua realização" (TERMINOU..., Jornal do Commercio, 30 jul. 1958, p. 14). O cronista interino da coluna Teatro (José Maria Marques) intitulou o evento como o "marco da maior festa de confraternização entre jovens amadores teatrais do Brasil" (INTERINO, Jornal do Commercio, 30 
jul. 1958, p. 14); enquanto Medeiros Cavalcanti, o titular da seção, que estava em viagem e não participou do Festival, tentou resumir o que aconteceu: "Soube que esteve bonito. Os conjuntos visitantes deram duro. Houve altos e baixos. O povo afluiu aos teatros. Filas. Confusões. Desordem. Vaia em político inábil que tentou aproveitar o clima artístico para 'acontecer' [o candidato a governador, Jarbas Maranhão]. Erros. Superlotações. E paraquedistas" (CAVALCANTI, Jornal do Commercio, 31 jul. 1958, p. 19).

Realmente uma série de problemas foi enfrentada, com as duas casas de espetáculos abarrotadas de espectadores, para além do permitido. E teve até protesto de participantes pela dificuldade de ver as apresentações. Ensaiou-se até uma vaia a Paschoal Carlos Magno. O público comum e a estudantada também não estavam satisfeitos. Somente no quarto dia do Festival a situação foi normalizada, com a distribuição de senhas, sujeitas ao necessário crivo: prioridade aos participantes do evento e aos estudantes portadores de carteira. Por conta do ingresso franqueado, enormes "enchentes de gente" foram registradas, principalmente no Teatro de Santa Isabel. Na imprensa, Valdemar de Oliveira aproveitou a ocasião e lembrou novamente sua maior queixa, a ausência de outras casas de espetáculos necessárias ao Recife, apontando, inclusive, que a Prefeitura poderia desapropriar o Teatro do Parque, fazendo voltá-lo de cinema a teatro, algo que realmente aconteceu no ano seguinte.

Assim que o evento chegou ao fim, o Curso de Arte Dramática da Escola de Belas Artes patrocinou, por mais cinco noites seguidas, palestras, conferência e espetáculos com o professor Alfredo Mesquita e o elenco da EAD. A iniciativa pretendia ampliar o intercâmbio artístico entre os dois centros de ensino. Para oferecer um espetáculo às crianças do Recife, a empresa Jornal do Commercio contratou A História do Mágico de Oz, do Teatro da Hebraica, realização da colônia israelita do Rio de Janeiro (dir. Jorge Levy), para nova sessão no dia 30 de julho de 1958, às 10 horas, no Teatro de Santa Isabel. E, atendendo a pedidos, a peça Morte e Vida Severina, de João Cabral de Melo Neto, com partitura musical de Waldemar Henrique e atuação do Norte Teatro Escola do Pará, considerado o melhor conjunto do Norte e que deu à Maria Sylvia Nunes o $3^{\circ}$ lugar de Melhor Diretora, também ganhou nova sessão naquela noite, sob patrocínio da Associação Brasileira de Escritores, Seção de Pernambuco.

O crítico Sábato Magaldi, vindo especialmente de São Paulo para cobrir o I Festival Nacional de Teatros de Estudantes, fez uma Ionga apreciação sobre os resultados do evento. Sem deixar de apontar contradições que precisavam ser repensadas, ele registrou que nunca tinha visto "teatro tão vivo e contagiante de vigor como na festa estudantil do Recife", surpreso por encontrar algumas das melhores montagens de cantos extremos do Brasil, e que "O velho e sempre atual conceito do teatro como expressão da vida coletiva encontrou no certame uma de suas manifestações mais autênticas" (MAGALDI, Jornal do Commercio, 17 ago. 1958, p. 6). E concluiu por lembrar:

Os resultados de um Festival só aparecem com o tempo e seria prematuro atribuir ao certame do Recife, desde já, uma importância que somente nos próximos anos se deve caracterizar. [...] Para a cidade do Recife, o Festival foi uma "promoção" do teatro absolutamente inédita que os conjuntos amadores locais precisam explorar, visando maior proveito da continuidade do seu trabalho (MAGALDI, Jornal do Commercio, 17 ago. 1958, p. 6).

Esse final da década de 1950 é realmente um período crescente de festivais de teatro no Brasil, tanto que em abril de 1958 foi criado o I Festival de Teatro Infantil, no Rio de Janeiro, no Teatro João Caetano, através do Serviço Nacional de Teatro, e que premiou Lígia Nunes como autora de O Bobo Bobão. O evento teve edições até 1961. Já em outubro de 1958 aconteceu o I Festival Brasileiro de Teatro de Bonecos, no Te $\rightarrow$ atro Nacional de Comédia, no Rio de Janeiro, numa promoção também do SNT, assim como o I Congresso Brasileiro de Teatro de Bonecos, no auditório do Ministério da Educação. Do "Norte", não foram poucas as tentativas de organização de festivais, todos no sonho de continuidade, e alguns até que conseguiram ${ }^{4}$.

Como o recorte temporal aqui ofertado dá atenção aos primeiros festivais de teatro no país, listo no próximo Quadro 5 alguns dos que puderam ser concretizados especificamente no Nordeste, o meu lugar de origem, até o final dos anos 1960 com ausências, é claro, e agradeço a contribuição de novas informações (houve uma explosão deles na década seguinte) -, além de outros eventos que, não sendo intitulados festivais, aconteceram no mesmo perfil, todos de fundamental importância 


\section{Quadro 5 - Outros festivais de teatro ou eventos no mesmo perfil realizados no Nordeste entre as décadas de 1950 e 1960}

I Festival de Teatro Amador da Bahia

I Festival de Teatro Matuto do Cariri

I Congresso Brasileiro de Teatro Amador

I Festival de Arte Dramática da Paraíba

I Festival do Teatro Cruzeiro da Vitória

I Festival Nortista de Amadores do Autor Teatral Brasileiro

I Semana de Teatro da Paraíba

I Festival de Teatro do Recife

I Semana do Teatro Universitário de Pernambuco

I Festival Nordestino de Teatros de Estudantes

I Encontro de Diretores de Teatros do NorteNordeste

I Festival de Artes de Penedo

I Festival Universitário de Teatro e Arte Popular

I Festival de Teatro Infantil de Pernambuco

Festival Martins Pena de Teatro Amador
1956 - Salvador/BA, com sequência de edições até 1959

1958 - Crato/CE, com nova edição em 1959 e sequência indefinida

$1958-N a t a l / R N$

1958 - João Pessoa/PB, com sequência de edições indefinida

1960 - Salvador/BA, com novas edições de 1962 a 1964

$1960-$ Natal/RN

1961 - João Pessoa/PB, com sequência de edições até 1969

$1961-$ Recife/PE

1962 - Recife/PE

1962 - Caruaru/PE

$1962-$ Natal/RN

1963 - Penedo/AL, com sequência de edições indefinida

1963 - Maceió/AL, com sequência de edições indefinida

$1963-$ Recife/PE

1965 - Recife/PE, Maceió/AL e outras capitais do país, incentivado pelo SNT 
I Festival de Teatro de Pernambuco

I Festival de Teatro do Nordeste

I Semana de Teatro
1967 - Recife/PE

$1969-$ Recife/PE

1969 - Campina Grande/PB, com sequência de edições indefinida

\begin{abstract}
* Muitos outros festivais surgiram no Nordeste, inclusive nos estados do Maranhão, Piauí e Sergipe, assim como em todo o restante do país, a partir da década de 1970, especialmente pelo impulso das federações estaduais e nacional (posteriormente, confederação) de teatro amador e movimento universitário.
\end{abstract}

como exemplos da sociabilidade dos fazedores teatrais na luta por sua arte no Brasil. E a cada novo encontro de prestígio ao segmento, o contato mais direto e constante com os públicos, gerando o imprescindível interesse renovado pelo palco.

\section{NOTAS}

01. Diferente do que dá a entender Fernando Peixoto (1993, p. 105) quando afirmou que a Federação Riograndense de Amadores Teatrais (FRAT) - de fato, a primeira que surgiu no Brasil, em 1948, sendo posteriormente fundadas as de São Paulo (1952) e da Bahia (1954) - "passou a organizar festivais com concurso todos os anos", relatando, inclusive, títulos de campeão concedidos ao Grupo dos 16, de Porto Alegre, nos anos de 1950 a 1952, ou seja, parecendo que o primeiro festival de teatro do país tenha ocorrido em terra gaúcha, no início daquela década, este dado não procede, pois somente em 1959 concretizouse o I Festival Gaúcho de Amadores Teatrais por aquela entidade, com edições até 1961. Fernando Peixoto refere-se, na verdade, não a um festival, mas ao Concurso de Amadores Teatrais promovido anualmente por aquela Federação. O curioso é que o secretário da FRAT, Maximiliano Weissheimer, garantiu que um primeiro festival de teatro amador tinha sido realizado "nos dias 8 a 17 de agosto de 1953 [ou seja, antes do I Festival Paulista de Teatro Amador], com a encenação dos originais O Diabo Enlouqueceu, Bruxa de Pano, Bodas de Prata e Não há Mais Nuvens no Céu, este do escritor gaúcho Bolívar Fontoura. O festival teve o alto e exclusivo patrocínio do Serviço Social do Comércio e foi supervisionado pela Federação Riograndense de Amadores Teatrais (FRAT)" (apud PEIXOTO, 1993. p. 69). O evento citado foi intitulado I Semana do Teatro Amador, sem a alcunha de festival, mas de mostra com aqueles quatro espetáculos locais, respectivamente do Grupo dos 16, Grupo Cênico São João, Corpo Cênico São Geraldo e Teatro Cinco de Setembro, todos apresentados no Teatro São Pedro e com entrada franca. Fica o registro, então.

02. Lançado em 2014, o Observatório dos Festivais é promotor de cursos e colaborador de eventos voltados ao tema. Através do site www.festivais. com.br apresenta os principais encontros no Brasil, com datas de realização e contatos, além de publicar artigos, notícias e resenhas. Junto ao Ministério da Cultura/FUNARTE, colabora no processo de construção de uma Política Nacional das Artes com foco na discussão das políticas públicas para os festivais e sua sustentabilidade, articulação de onde surgiu, informalmente, a Rede de Festivais, composta hoje por dezenas de festivais de todo o país, com destaque ao Núcleo dos Festivais Internacionais de Artes Cênicas do Brasil, cuja origem é de 2003.

03. Pela ausência de mais espaço neste artigo, fica impossível elencar maiores detalhes (ver a respeito o dossiê "Os festivais de teatro amador no Brasil", organizado por Aldomar Conrado e incluído em O Percevejo - Revista de Teatro, Crítica e Estética, publicação do Departamento de Teoria do Teatro/Programa de Pós-Graduação em Teatro da UNIRIO, edição 2001/2002, p. 225-335), mas aqui vou me ater ao festival 
que daqueles deu o pontapé a tão importante iniciativa, servindo de exemplo a muitas outras programações Brasil afora.

04. São exemplos de festivais no Norte do Brasil daquela época: o Festival de Teatro Infantil e o Festival da Cultura. O primeiro ocorreu na cidade de Manaus por duas edições, em 1965 e 1966, numa ação do diretor teatral, dramaturgo e produtor Alfredo Fernandes quando esteve na direção do Teatro Amazonas. Com apoio do Governo do Estado, somente peças dele foram exibidas, Lágrimas de Brinquedo, A Bruxa de Louça e Um Brinquedo Atrás da Porta na primeira versão, e estas mesmas, além de Dois Anjinhos de Castigo, Um Brinquedo Igual a Gente e Bonecas da Mesma Cor, na segunda e última, também com promessas de chegar às cidades de Parintins e Itacoatiara. Já o Festival da Cultura, que incluía programação teatral adulta e infantil competitiva naquela mesma casa de espetáculos, numa promoção da Fundação Cultural do Amazonas, teve edições de 1967 até 1970. Mais detalhes podem ser lidos em duas publicações da dupla Selda Vale e Ediney Azancoth: Cenário de Memórias - Movimento Teatral em Manaus (1944-1968). Manaus: Editora Valer: Governo do Estado do Amazonas, 2001. p. 341-361; e TESC - Nos Bastidores da Lenda. Manaus: Editora Valer: SESC, 2009. p. 31-53.

\section{REFERÊNCIAS}

BONES, Marcelo. Um olhar sobre os festivais. In: Catálogo Palco Giratório - Circuito Nacional 2017. Rio de Janeiro: SESC (Serviço Social do Comércio): Departamento Nacional, 2017. p. 22.

CASTRO, Luiz Inácio F. de. Empresários veem crise no teatro. Correio da Manhã. Rio de Janeiro, 26 ago. $1967.1^{\circ}$ Caderno. p. 7.

CAVALCANTI, Medeiros. Desserviço. Jornal do Commercio. Recife, 27 set. 1955. Artes e Artistas/Teatro. p. 6.

CAVALCANTI, Medeiros. O interino. Jornal do Commercio. Recife, 31 jul. 1958. Artes e Artistas/Teatro. p. 19.

CONRADO, Aldomar (org.). Dossiê: Os festivais de teatro amador no Brasil. In: O Percevejo - Revista de Teatro, Crítica e Estética. Rio de Janeiro:
Departamento de Teoria do Teatro: Programa de Pós-Graduação em Teatro da Universidade do Rio de Janeiro (UNIRIO). Anos 9/10. № 10 e 11. Edição 2001/2002. p. 225-335.

FONTANA, Fabiana Siqueira. o Teatro do Estudante do Brasil de Paschoal Carlos Magno. Rio de Janeiro: Funarte, 2016.

GARCIA, Clóvis. Os Caminhos do Teatro Paulista: um panorama registrado em críticas - O Cruzeiro (1951-1958), A Nação (1963-1964). São Paulo: Prêmio Editorial Ltda., 2006. p. 243.

GUINSBURG, J.; FARIA, João Roberto; LIMA, Mariângela Alves de (orgs.). Dicionário do Teatro Brasileiro: temas, formas e conceitos. São Paulo: Perspectiva: SESC São Paulo, 2006. p. 61.

INTERINO [José Maria Marques]. As últimas notas. Jornal do Commercio. Recife, 30 jul. 1958. Artes e Artistas/Teatro. p. 14.

KÜHNER, Maria Helena. Teatro Amador: radiografia de uma realidade. Rio de Janeiro: INACEN, 1987. p. 11.

MAGALDI, Sábato. O festival do Recife. Jornal do Commercio. Recife, 17 ago. 1958. Segundo Caderno/Arte. p. 6.

METZLER, Marta. 0 Teatro da Natureza: história e ideias. São Paulo: Perspectiva, 2006.

MOLINA, Diego. Teatro Duse: o primeiro teatrolaboratório do Brasil. Rio de Janeiro: Funarte, 2015. p. 107-108.

NIMTZOVITCH, Oscar. O regulamento... do "Festival Paulista de Teatro Amador". Correio Paulistano. São Paulo, 14 set. 1954. Comédia. p. 7.

PAVIS, Patrice. Dicionário de Teatro. Tradução para a língua portuguesa sob a direção de J. Guinsburg e Maria Lúcia Pereira. São Paulo: Perspectiva, 1999. p. 166.

PEIXOTO, Fernando. Um Teatro Fora do Eixo Porto Alegre: 1953-1963. São Paulo, Editora Hucitec, 1993. p. 69;105.

ROSA, Marcus Wesley Guimarães. Projeto Teatro Amador - Cultura de Estado: políticas públicas e censura em relação ao teatro amador. Universidade de São Paulo: Escola de Comunicações e Artes: Relatório final CNPQ/ 
PIBIC. São Paulo, set. 2008. p. 31-32. Disponível em: $\quad$ <http://www2.eca.usp.br/ams/pub/ relat/2009PIBIC_MarcusWesleyGuimaraesRosa. pdf >. Acesso em: 24 mai. 2020.

TERMINOU o "Festival de Teatro": a relação completa dos premiados. Jornal do Commercio. Recife, 30 jul. 1958. p. 14.

VALE, Selda; AZANCOTH, Ediney. Cenário de Memórias - Movimento Teatral em Manaus (1944-1968). Manaus: Editora Valer: Governo do Estado do Amazonas. p. 341-361.

VALE, Selda. TESC - Nos Bastidores da Lenda. Manaus: Editora Valer: SESC, 2009. p. 31-53.

VIOTTI, Sérgio. Dulcina e o Teatro de Seu Tempo. Rio de Janeiro: Lacerda Ed., 2000. p. 454;456.

W. [Valdemar de Oliveira]. A propósito... Jornal do Commercio. Recife, 25 set. 1955. Artes e Artistas. p. 6.

W. [Valdemar de Oliveira]. Subvenções do SNT. Jornal do Commercio. Recife, 27 set. 1955. Artes e Artistas/A propósito... p. 6.

\section{SOBRE O AUTOR}

Leidson Malan Monteiro de Castro Ferraz é doutorando no Programa de Pós-Graduação em Artes Cênicas da Universidade Federal do Estado do Rio de Janeiro - UNIRIO (previsão de término: 2022), Mestre no Programa de PósGraduação em História da Universidade Federal de Pernambuco (2018), na linha de pesquisa em "Cultura e Memória", e jornalista formado pela Universidade Católica de Pernambuco (1995), com larga experiência na área da Cultura, em especial no segmento do Teatro e da Dança. Pesquisador, professor e autor de livros sobre a história do Teatro Pernambucano, além de crítico teatral. Tema da dissertação defendida: "O Teatro no Recife da Década de 1930: outros significados à sua história". 